\title{
Genetic susceptibility in familial melanoma from northeastern Italy
}

\author{
M T Landi, A M Goldstein, S Tsang, D Munroe, W Modi, M Ter-Minassian, R Steighner, M Dean, \\ N Metheny, B Staats, R Agatep, D Hogg, D Calista
}

J Med Genet 2004;41:557-566. doi: 10.1136/jmg.2003.016907

C utaneous malignant melanoma (CMM) is a potentially fatal form of skin cancer, whose incidence and Approximately $3-12 \%$ of cutaneous malignant melanoma develops in families with multiple cases of melanoma. ${ }^{3-5}$ Worldwide studies of large families prone to melanoma have demonstrated linkage to a locus on chromosome 9p21 (MIM 600160 ) in the majority of kindreds, and probable linkage to $1 p 22^{6}$ and $1 p 36^{78}$ in others. About one third of $9 p 21$ linked families carry mutations in the CDKN2A tumour suppressor gene, ${ }^{9}{ }^{10}$ which encodes the pl6 cell cycle inhibitor. Rare kindreds may also possess mutations of the coding sequences of CDK4 (MIM 12829), ${ }_{11}^{12}$ or $p 14^{A R F}$ (translated from exons $1 \beta$ and 2 of $C D K N 2 A) .{ }^{13-15}$ More studies are needed to understand the genetic basis of melanoma.

In Italy, the melanoma prone families studied to date are mostly from the north ${ }^{16}$ and northwestern areas, ${ }^{15} 1718$ the centre, ${ }^{19}$ and the Sardinia region. ${ }^{20}$ These families are generally characterised by small numbers of melanoma cases, and a relatively high frequency of $C D K N 2 A$ mutations.

We studied families prone to melanoma from northeastern Italy, to characterise genetic susceptibility to melanoma in this population.

\section{MATERIALS AND METHODS \\ Study population}

The study group was comprised of 55 families: 44 (80\%) from southern Emilia Romagna and northern Marche (close to the border between the two regions); 10 families, all with two cases per family, from other areas of Italy (four from the south, three from the centre, two from the north, and one from Sardinia), and one family from Russia. All the families were recruited at the Dermatology Unit of the Bufalini Hospital in Cesena, Italy. Bufalini Hospital's and the National Cancer Institute's Ethical Committees approved the study, and written informed consent was obtained from all participants. In the study period, the Bufalini Hospital examined approximately $85 \%$ of all cutaneous malignant melanoma patients from the Marche and Emilia Romagna area, as verified with the Romagna regional cancer registry ${ }^{21}$ and with records of melanoma diagnoses from the main hospitals of the area. ${ }^{22}$ Thus, the families coming from Marche and Emilia Romagna region are representative of the study area. The characteristics of these families are reported in table 1. All subjects answered an interview based questionnaire and donated a blood sample, which was immediately processed to obtain cryopreserved lymphocytes and serum samples. A single dermatologist (DC) examined all subjects, and diagnosed melanoma and dysplastic nevi. A dysplastic nevus had to be $\geqslant 5 \mathrm{~mm}$, predominantly flat, and have at least two of the following criteria: variable pigmentation, indistinct borders, and irregular outline. ${ }^{23}$ All cases of melanoma and any other tumours in the cases of melanoma were confirmed histologically. Melanoma

\section{Key points}

- We studied 55 families prone to melanoma and having at least two relatives with melanoma, mostly from the Emilia Romagna and Marche regions of Italy. Cases with multiple primary melanomas, dysplastic nevi, and pancreatic cancer were present in several families. We sequenced CDKN2A in all families, and screened CDKN2B, p1 $4^{A R F}$, and CDK4 in a subset. In families with more than one case of breast or gastric cancer, we also sequenced BRCA2 and CDH1. We performed linkage analysis of chromosomes 1 and 9, which harbour loci previously linked to melanoma susceptibility. We examined the effect of a novel CDKN2A mutation on the p16 protein tertiary structure and function.

- Three known p16 mutations, G101W, R24P, and S56l, and a novel L65P were identified in four kindreds, accounting for $7 \%$ of all families. The L65P mutation caused a small distortion of 16 tertiary structure and reduced binding to CDK4 by $50 \%$ in a yeast two hybrid assay. No disease related mutations were found in the other tested genes. There was no evidence for linkage to either chromosome 1 or 9.

- We conclude that germline alterations of one or more genes other than CDKN2A, and on chromosome loci other than those previously identified, may be important for melanoma predisposition. The population of northeastern Italy may be a rich source for further genetic studies on melanoma.

diagnosis was reviewed in $40 \%$ of the cases by three independent pathologists, with $99 \%$ concordance with the original diagnosis.

\section{CDKN2A gene analysis}

The promoter and the three exons of CDKN2A were amplified from the genomic DNA extracted from the patient blood samples. The reaction mix for PCR amplification of the promoter region included $1 \times \mathrm{PCR}$ buffer (Invitrogen High Fidelity PCR buffer); $2.2 \mathrm{mM} \mathrm{MgSO}{ }_{4} ; 5 \%$ DMSO; $175 \mathrm{nM}$ of each pair of primers; $50 \mathrm{nM}$ of each of the four dNTPs and 1 unit of HiFi Platinum Taq polymerase (Invitrogen). This mix was also used in the amplification of the three exons with changes of $2 \mathrm{mM} \mathrm{MgSO}_{4}$ and $5 \%$ DMSO for exons $\mathrm{l}$ and 2, and $3 \mathrm{mM} \mathrm{MgSO}_{4}$ and 3\% DMSO for exon 3 in the final PCR mix. The PCR for the promoter and exon 3 were

Abbreviations: $\mathrm{BCC}$, basal cell carcinoma; $\mathrm{CMM}$, cutaneous malignant melanoma; DN, dysplastic nevi; STS, soft tissue sarcoma 
programmed with 40 cycles of amplification on a Perkin Elmer PCR cycler. The amplification programme of each cycle consisted of $60 \mathrm{~s}$ at $95^{\circ} \mathrm{C}, 60 \mathrm{~s}$ at the annealing temperature and $60 \mathrm{~s}$ at $72^{\circ} \mathrm{C}$. A $3 \mathrm{~min}$ initial denaturing step at $95^{\circ} \mathrm{C}$ and a $10 \mathrm{~min}$ final extension step at $72^{\circ} \mathrm{C}$ were included in both PCRs. The annealing temperature was $55^{\circ} \mathrm{C}$ for the amplification of the promoter and $58^{\circ} \mathrm{C}$ in exon 3. The PCR of exons 1 and 2 involved a "touchdown" thermal cycling with two cycles at each decreased annealing temperature. The method then followed that of Castellano et $\mathrm{al}^{24}$ and Pollock et al. ${ }^{25}$ All products were run on DNA 1000 labchips using "lab-on-achip" capillary electrophoresis (Agilent, Palo Alto, CA). All PCR products were treated with shrimp alkaline phosphatase and exonucleaseI (ExoI), ${ }^{26}$ and followed by the use of a 96 well plate of G-50 Sephadex to clean the PCR product before sequencing. All products were sequenced with ABI prism BigDye terminator cycle sequencing kit 1.0 (Applied Biosystems Inc.) on an ABI3700 sequence analyser. The PCR primers of the promoter and exon 2 were previously described by Pollock et $\mathrm{al}^{25}$ The DNA sequences of the primers used for $C D K N 2 A$ amplification and sequencing were: promoter, amplification: $\mathrm{P} 96 \mathrm{~F}$ and $\mathrm{P} 968 \mathrm{R},{ }^{25}$ sequencing: $2 \mathrm{~F}$ TGCCCCAGACAGCCGTTTTAC; IR ACGACTAGAAAGTGTCC; with P96F and P968R; exon 1, amplification: P781F ${ }^{25}$; 4RGCGCTACCTGATTCCAATTC; sequencing: 4F-CAGCACCG GAGGAAGAAAG; 3R-TGCCTGCTCTCCCCCTCT; with P781F and 4R; exon 2, amplification with $42 \mathrm{~F}$ and $551 \mathrm{R}^{25}$ sequencing with $5^{\prime}$-CTGAACTTTCTGTGCTGG and $42 \mathrm{~F} ;{ }^{25}$ exon 3, amplification, and sequencing with 11F-CAGTGGA CTAGCTGCTGGAC; 11R-ATGGACATTTACGGTAGTGGG. All sequences were analysed and variants were detected using Mutation Surveyor (SoftGenetics Inc., PA).

\section{Analysis of $P 14^{A R F}$ ( $\beta$ transcript), CDKN2B, and CDK4 genes}

PCR was performed by amplifying $30 \mathrm{ng}$ of genomic DNA in $20 \mu \mathrm{l}$ in $10 \mathrm{mM}$ Tris- $\mathrm{HCl}, \mathrm{pH} 8.3,50 \mathrm{mM} \mathrm{KCl}, 1.5 \mathrm{mM}$ $\mathrm{MgCl}_{2}, 200 \mu \mathrm{M}$ of each dNTP, 6 pmol of each primer, and 0.02 units of Taq Gold DNA polymerase (Perkin-Elmer). Cycling conditions included an initial $94^{\circ} \mathrm{C}$ denaturation step for $10 \mathrm{~min}$, then 35 cycles of $94^{\circ} \mathrm{C}$ denaturation for $30 \mathrm{~s}, 57-$ $62^{\circ} \mathrm{C}$ annealing for $1 \mathrm{~min}$, and a $72^{\circ} \mathrm{C}$ extension step for $1 \mathrm{~min}$, ending with a $72^{\circ} \mathrm{C}$ step for $5 \mathrm{~min}$.

PCR for SSCP was conducted with the addition of $0.04 \mu \mathrm{l}$ of a32P-dCTP (3000Ci/mMol, New England Nuclear Inc.) to each reaction. Following PCR, $10 \mu \mathrm{l}$ of stop solution $(0.05 \%$ each of bromphenol blue and xylene cyanol in 100\% foramide) were added to each reaction. The products were heated at $95^{\circ} \mathrm{C}$ for $5 \mathrm{~min}$ and then quickly chilled on ice. Products were separated in vertical acrylamide slab gels.

PCR products were directly sequenced using Big Dye chemistry (Applied Biosystems Inc. (ABI). Products were purified using Qiagen Inc. quick spin columns. Electrophoresis was carried out on an ABI 377 automated fluorescent DNA sequencing machine. Nucleotide sequences were aligned and analysed using Sequencher software (Gene Codes Inc.). Primers for $C D K N 2 B$ were as described in Liu et $\mathrm{al}^{27}$; primers for the $\beta$ transcript were as described in Mao

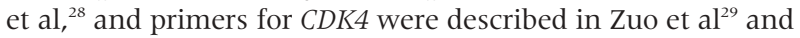
Shennan et al. ${ }^{30}$

\section{Genome wide scan of chromosomes 1 and 9}

The marker set genotyped in this study was the Applied Biosystems Inc. (ABI) linkage mapping set version 2.5 (MD10) with 31 (for chromosome 1) and 20 (for chromosome 9) dinucleotide microsatellites arranged into panels with an average heterozygosity of 0.79 and a resolution of approximately $10 \mathrm{cM}$ between markers. Microsatellites were genotyped by consolidating the amplification reactions into 3-5 reactions per panel, each containing 2-5 markers. The products of each multiplex were pooled by panel, diluted and mixed with deionised formamide and size standard before electrophoresis. Multiplex PCRs were designed with respect to dye colour, marker size, and quality of amplification product obtained. Failed amplifications were reamplified either singly or in redesigned multiplexes.

Each PCR reaction mix contained primers of $0.15-5$ pmol per marker, $20 \mathrm{ng}$ of genomic DNA, and $3 \mu \mathrm{l}$ of ABI True Allele Mix in a total reaction volume of $5 \mu$ l. Reaction conditions (MJ Research PTC-225 Tetrad) were $95^{\circ} \mathrm{C}$ for $12 \mathrm{~min}$ followed by 10 cycles at $94^{\circ} \mathrm{C}$ for $15 \mathrm{~s}, 53^{\circ} \mathrm{C}$ for $15 \mathrm{~s}$, and $72^{\circ} \mathrm{C}$ for $30 \mathrm{~s}$ and then 22 cycles at $89^{\circ} \mathrm{C}$ for $15 \mathrm{~s}, 53^{\circ} \mathrm{C}$ for $15 \mathrm{~s}$, and $72^{\circ} \mathrm{C}$ for $30 \mathrm{~s}$ with a final $10 \mathrm{~min}$ extension step at $72^{\circ} \mathrm{C}$. Following amplification each multiplex was diluted to $10 \mu \mathrm{l}$ with $\mathrm{ddH}_{2} \mathrm{O}$ and $2 \mu \mathrm{l}$ were pooled per individual ABI panel. Two microlitres of each pooled panel or individual multiplex were mixed with $0.4 \mu \mathrm{l}$ GS500LIZ size standard and $7.6 \mu \mathrm{l}$ deionised formamide prior to electrophoresis. Electrophoresis was performed in either 96 or 384 well plates on an ABI 3100 capillary electrophoresis instrument. Fluorescent peak data were sized using ABI GeneScan Analysis version 3.7 and allele calling performed using Genotyper 3.7 software. Allele calling consistency between plates was verified through positive controls and verification of individual genotypes obtained by concordance of the pooled multiplex genotypes with those of the individual multiplexes. Genotypes were assigned blind to pedigree structure and clinical data.

\section{Linkage analysis of chromosomes 1 and 9}

Power calculations based on simulation studies on the 47 families tested for linkage revealed $85 \%$ power to detect a lod score higher than 3 (expected maximum lod score of 4.15), under a dominant model with $50 \%$ penetrance and the

Table 1 Family characteristics

\begin{tabular}{|c|c|c|c|c|c|c|c|}
\hline \multirow{2}{*}{$\begin{array}{l}\text { No } \mathrm{CMM} \\
\text { in family }\end{array}$} & \multirow[b]{2}{*}{ No families } & \multirow{2}{*}{$\begin{array}{l}\text { Mean age at } \\
\text { CMM diagnosis* }\end{array}$} & \multicolumn{3}{|c|}{ Families with } & \multirow{2}{*}{$\begin{array}{l}\text { Other cancers in } \\
\text { melanoma cases }\end{array}$} & \multirow[b]{2}{*}{ No families by region } \\
\hline & & & MPM & DN & PC & & \\
\hline 2 & 42 & 50 & 11 & 40 & 2 & 8 subjects: & $32=$ Emilia Romagna + Marche $; 10=$ others \\
\hline $7^{\text {st }}$ degree & 34 & 51 & 6 & 33 & 2 & $\begin{array}{l}\text { adnexal, BCC, } \\
\text { breast, kidney, STS, } \\
\text { testicular, thyroid }\end{array}$ & $\begin{array}{l}25=\text { Emilia Romagna+Marche; } 9=\text { Abruzzi, } \\
\text { Campania, Friuli, Puglia, Sardinia, Tuscany }\end{array}$ \\
\hline$\geqslant 2^{\text {nd }}$ degree & 8 & 46 & 5 & 7 & 0 & throat & 7=Emilia Romagna + Marche; $1=$ Lombardy \\
\hline 3 & 11 & 48 & 3 & 9 & 0 & $\begin{array}{l}2 \text { subjects: } B C C \text {, } \\
\text { kidney, prostate }\end{array}$ & $10=$ Emilia Romagna + Marche $; 1=$ Russia \\
\hline 4 & 1 & 48 & 1 & 1 & 1 & 0 & $1=$ Emilia Romagna \\
\hline 5 & 1 & 43 & 0 & 1 & 0 & 0 & $1=$ Emilia Romagna \\
\hline
\end{tabular}

CMM, cutaneous malignant melanoma; MPM, multiple primary melanomas; DN, dysplastic nevi; PC; pancreatic cancer, BCC; basal cell carcinoma; STS, soff tissue sarcoma

*For multiple primary melanomas, the first diagnosed melanoma was considered 
assumption of no heterogeneity, using a simulated marker with six equally frequent alleles.

Parametric two point and multipoint linkage analyses for chromosomes 1 and 9 were performed, using MLINK (v. 5.1) of the FASTLINK (v. 4.lp) software package,, ${ }^{31}$ and GENEHUNTER (V. 2.0ß), ${ }^{33}$ respectively, assuming an autosomal dominant inheritance model with $50 \%$ penetrance. The disease frequency under the dominant model was calculated as 0.0004 based on the prevalent sex averaged rate of melanoma in the Italian population of $60 / 100000 .{ }^{34}$ Only individuals diagnosed with cutaneous malignant melanoma were coded as affected. For genotyped data, Mendelian inconsistencies were found in $0.15 \%$ using PEDCHECK (v. 1.1). ${ }^{35}$ Erroneous genotypes were reread, changed, or dropped because of non-paternity $(0.04 \%)$. Marker allele frequencies were calculated using RECODE (v. 1.4) (http://watson.hgen. pitt.edu/register), based on founder and married-in individuals. The analysis was conducted on the entire set of families after the exclusion of non-informative families or families with positive mutations in candidate genes: 47 families were used for the analysis of chromosome 1 and 46 families for chromosome 9. We also repeated the analysis excluding the eight families with melanoma only in second or further degree relatives. The exclusion did not appreciably alter the results. Thus, data from these eight families are reported in the manuscript.

Non-parametric multipoint linkage analysis was also performed using GENEHUNTER (v. $2.0 \beta$ ). The Marshfield genetic maps ${ }^{36}$ were used to determine order and distance between markers. We tested for genetic heterogeneity using GENEHUNTER (v. $2.0 \beta$ ) and HOMOG (v. 3.35). ${ }^{37} 38$

Analysis of the 3D structure of the p 16 INK4a protein All predictive mutational effects on protein structure were carried out using publicly available web services, as reported in Guerois et $\mathrm{al}^{39}$ for FOLD-X calculations; in Gilis et $\mathrm{al}^{40}$ for PoPMuSiC calculations; and in Sunyaev et $\mathrm{al}^{41}$ for PolyPhen calculations.

\section{Analysis of the interaction of $p 16$ wild-type and mutant to CDK4 by a yeast two hybrid system}

The growth and maintenance of $S$. cerevisiae was performed using methods described in Guthrie and Fink. ${ }^{42}$ Two hybrid analysis was carried out in the yeast strain RAY43 (MATa ura3-52 his3-200 leu2-3, -112; trp 1-901; Can r gal4-542; gal80-

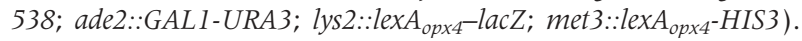
Both pBTMI16 $6^{43}$ and pACTII (Clontech) were used for two hybrid analysis. The strategies used to generate the vectors pBTM116-pl6WTlexA, pBTM116- pl6L65PlexA, and pACTIIGAL4ADCDK4 are available on request. All two hybrid vectors were sequenced to confirm the absence of PCR generated nucleotide substitutions and to ensure that the appropriate frame was maintained throughout the entire fusion gene. Plasmids were transformed into the RAY43 strain as described in Gietz and Woods. ${ }^{44}$ Quantitative analysis of $\beta$-galactosidase activity was performed using a modification of the method of Miller. ${ }^{45}$ Mean values for liquid $\beta$-galactosidase assays were derived from 28 independent experiments at $30^{\circ} \mathrm{C}$ and 20 separate experiments at $37^{\circ} \mathrm{C}$. The $\beta$-galactosidase activity (defined in Miller units) was measured using the following formula:

$$
\begin{aligned}
& \beta-\text { galactosidase activity } \\
& =\frac{\left(1000 \times O D_{570}\right)}{\left(\text { Time }[\mathrm{min}] \times \text { Volume }[\mathrm{ml}] \times O D_{405}\right)}
\end{aligned}
$$

pl6WT and pl6L65P $\beta$-galactosidase activity were compared assuming homoscedasticity using a two tailed Student's $t$ test.

\section{CDH 1 gene analysis}

PCR was performed by amplifying $2.0 \mu \mathrm{l}$ of genomic DNA in a $25 \mu \mathrm{l}$ reaction containing $2.5 \mu \mathrm{l}$ of $10 \times$ buffer, $0.2 \mu \mathrm{l}$ of dNTPs, $0.1 \mu \mathrm{l}$ of Taq Gold DNA polymerase (Perkin-Elmer), $2.0 \mu \mathrm{l}$ of oligonucleotide primers, ${ }^{46}$ and $18.2 \mu \mathrm{l}$ of water. Cycling conditions included an initial $94^{\circ} \mathrm{C}$ denaturation step for $10 \mathrm{~min}$, followed by 12 cycles of $94^{\circ} \mathrm{C}$ denaturation for $12 \mathrm{~s}, 65^{\circ} \mathrm{C}$ annealing for $20 \mathrm{~s}$, and a $72^{\circ} \mathrm{C}$ extension step for $55 \mathrm{~s}$ with a reduction of $0.5^{\circ} \mathrm{C}$ of annealing temperature with each cycle. The procedures then followed 30 cycles: $94^{\circ} \mathrm{C}$ denaturation for $12 \mathrm{~s}, 50^{\circ} \mathrm{C}$ annealing for $20 \mathrm{~s}$, and a $72^{\circ} \mathrm{C}$ extension step for $55 \mathrm{~s}$, ending with a $72^{\circ} \mathrm{C}$ step for $7 \mathrm{~min}$.

PCR products were directly sequenced using the High Pure Plasmid Isolation Kit (Boehringer Mannheim, Inc.). Electrophoresis was carried out on an ABI 310 automated DNA sequencing machine. Nucleotide sequences were aligned and analysed using Seqman software.

\section{BRCA2 gene analysis}

Full sequence determination in both forward and reverse directions of approximately 10200 base pairs containing 26 coding exons and approximately 900 adjacent base pairs in the introns (not more than 20 base pairs proximal to the $5^{\prime}$ end and 10 base pairs distal to 3' end of each exon) was conducted under contract at Myriad Genetics Laboratories. Exon 1, which is non-coding, was not analysed. Patient DNA was subjected to 47 PCR reactions. The amplified products were each directly sequenced in forward and reverse directions using fluorescent dye labelled sequencing primers. Chromatographic tracings of each amplicon were analysed by a proprietary (BRACAnalysis, Myriad Genetics Laboratories) computer based review followed by visual inspection and confirmation.

\section{RESULTS CDKN2A gene}

We sequenced $C D K N 2 A$ in melanoma affected and unaffected members of 55 families. Four mutations in the CDKN2A gene were found in seven different members of four kindreds (table 2). Three mutations, G101W, R24P, and S56I, have already been found in many families, including Italians. ${ }^{16} 1947$ The fourth potentially disease related mutation we found was a novel $\mathrm{T}$ to $\mathrm{C}$ transition at bp 194 of exon 2, which results in a missense mutation L65P in pl6 and a silent mutation A79A in pl4 ${ }^{\mathrm{ARF}}$. This mutation was found in a family with one patient having pancreatic cancer and four patients with melanoma, one of whom had two primary melanomas (fig 1 ). Three cases of cutaneous malignant melanoma and one unaffected family member, who had had several nevi removed for suspected but not confirmed melanoma, carried this mutation. The fourth patient with melanoma was deceased and could not be tested for this mutation. We also found the same mutation in a 39 year old unaffected member of another family from the same geographic area with five individuals with melanoma. Unfortunately, all of these individuals except one were deceased, and thus could not be tested for any CDKN2A mutation. The only living individual with cutaneous malignant melanoma, and seven other unaffected family members, did not carry CDKN2A mutations.

Among the families positive for mutations, $75 \%$ of carriers were affected. In these subjects, melanoma lesions were either of the superficial spreading or nodular histologic type, with thicknesses ranging from $0.8 \mathrm{~mm}$ to $10 \mathrm{~mm}$, and Clark levels from II to IV. Their age at diagnosis did not differ significantly from that of the cases with no detected CDKN2A mutations. All the mutations were found in families from the Emilia Romagna region, with the exclusion of R24P, which was found in a family from Naples (Campania). 


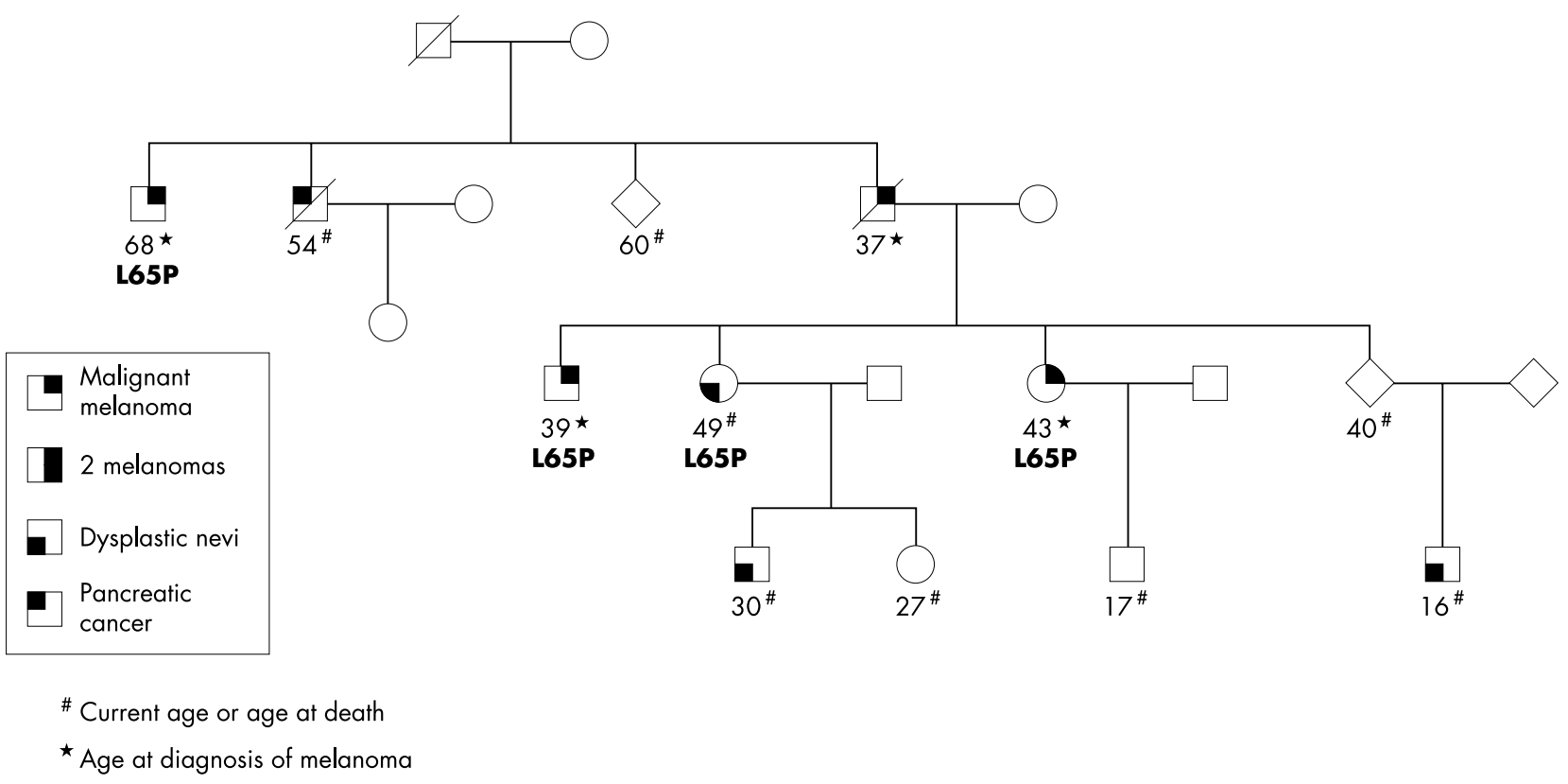

Figure 1 Pedigree of the family with p16 L65P mutation, from the Emilia Romagna region, Italy.

We found two additional alterations that do not appear to be related to disease in two other families with two first degree relatives with melanoma: a mutation of intron 1 $($ IVS $1+38)$, present only in a 12 year old unaffected individual, and a $G$ to A mutation at bp 384 in exon 2, which results in a silent mutation R128R (and occurs on the 3' UTR of $p 14^{A R F}$ ), present in one affected and one 54 year old unaffected individual from the same family.

We also found several known polymorphisms and a sequence variant of uncertain significance in $C D K N 2 A$ exon 2, exon 3, and the promoter area. Specifically, 10 families carried the exon 2 polymorphism at bp 442, which results in the Al48T amino acid change. ${ }^{48}$ Five sequence variants were found in the promoter area: $\mathrm{P}-493^{48}$ was found in nine of the ten subjects who carried the Al48T variant, consistent with the previously reported linkage disequilibrium between these two loci ${ }^{47}{ }^{48}$; P-981 ${ }^{25}$ was found in five families; P-735 $5^{48}$ was found in two families; P- $191^{48}$ was found in $59 \%$ of the patients and in $74 \%$ of the unaffected individuals; and a novel P-745 was found in one patient only. This cutaneous malignant melanoma patient also carried the Al48T and $\mathrm{P}-493$ variants, but had no mutations in the coding region. In the $3^{\prime}$ UTR, the $500 \mathrm{G}>\mathrm{C}$ polymorphism ${ }^{49}$ was found in $28 \%$ of cases and $37 \%$ of unaffected individuals; the $540 \mathrm{C}>\mathrm{T}$ polymorphism $^{49}$ was found in $23 \%$ of cases and $24 \%$ of unaffected individuals.

We analysed the changes in the tertiary structure of the p16 protein due to the novel L65P mutation. Leu65Pro (fig 2) is at the last residue position in helix 6 and thus could shorten the helix and disrupt secondary structure. It is unclear how this would alter the tertiary structure, but the solvent accessibility at this position would suggest a relatively small distortion. The removal of the methyl groups at this position could disrupt external interactions with other proteins. Both the FOLD-X calculations $(\mathrm{ddG}=21.38 \mathrm{~kJ} /$ $\mathrm{mol})$, and the PoPMuSiC calculations $(\mathrm{ddG}=5.77 \mathrm{~kJ} / \mathrm{mol}$ ) revealed a difference in folding energy between the mutant and wild-type protein, but the PolyPhen predictions, based on alignment, failed to predict this mutation to be disruptive on protein function (the leucine at position 65 is not highly conserved in mammals).

To confirm the conclusions derived from protein modelling, we elected to test the interaction of the L65P mutant to CDK4 using a yeast two hybrid system. We expressed the mutant and wild-type cDNA sequences in the presence or absence of CDK4 and measured their corresponding

Table 2 Characteristics of families with CDKN2A mutations

\begin{tabular}{|c|c|c|c|c|c|c|c|c|c|}
\hline \multicolumn{2}{|c|}{ CDKN2A mutations } & \multirow{2}{*}{$\begin{array}{l}\text { No CMM } \\
\text { in family }\end{array}$} & \multirow{2}{*}{$\begin{array}{l}\text { Breslow and } \\
\text { Clark levels }{ }^{\dagger}\end{array}$} & \multirow{2}{*}{$\begin{array}{l}\text { Mean age at } \\
\text { diagnosis in cases } \\
\text { with mutations* }\end{array}$} & \multirow[b]{2}{*}{ MPM } & \multirow[b]{2}{*}{$\mathrm{DN}$} & \multirow{2}{*}{$\begin{array}{l}\text { Pancreatic } \\
\text { cancer in } \\
\text { family }\end{array}$} & \multirow{2}{*}{$\begin{array}{l}\text { Other cancers } \\
\text { in family }\end{array}$} & \multirow[b]{2}{*}{ Region } \\
\hline p16 & p14ARF & & & & & & & & \\
\hline G101W & R115L & 2 & $\begin{array}{l}B=10 \mathrm{~mm} \\
C=I V\end{array}$ & 59 & No & No & Yes & $\begin{array}{l}\text { gastric, prostate, } \\
\text { uterine }\end{array}$ & Emilia Romagna \\
\hline R24P & - & 2 & $\begin{array}{l}B=1 \mathrm{~mm} \\
C=I I I\end{array}$ & 22 & No & Yes & No & bladder & Campania \\
\hline S56I & Q70H & 2 & $\begin{array}{l}\mathrm{B}=1.3 \mathrm{~mm} \\
\mathrm{C}=\mathrm{IV}\end{array}$ & 61 & Yes & Yes & No & breast & Emilia Romagna \\
\hline L65P & A79A & 4 & $\begin{array}{l}B=0.8-2.8 \mathrm{~mm} \\
C=I-I V\end{array}$ & 47 & Yes & Yes & Yes & $\begin{array}{l}\text { breast, lung, } \\
\text { prostate }\end{array}$ & Emilia Romagna \\
\hline
\end{tabular}

CMC, cutaneous malignant melanoma; MPM, multiple primary melanomas; DN, dysplastic nevi.

*For multiple primary melanomas, the first diagnosed melanoma was considered.

${ }^{\dagger}$ Melanoma thickness in cases with CDKN2A mutations. The fourth family had three cases with L65P. The range of melanoma thickness in the three cases is reported.

FIn first degree relatives. 


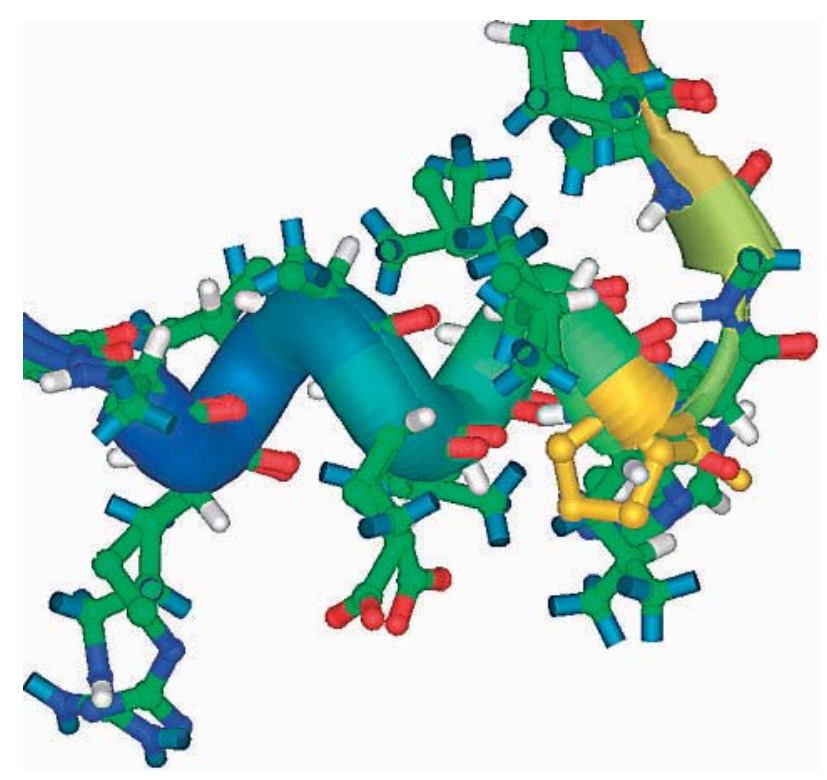

Figure 2 Structural model of the leucine to proline substitution at position 65 of p 16 protein. The model shows that the proline amino acid (in bright yellow), unlike the leucine (behind the proline, in green), no longer makes hydrogen atoms available to the surface of the protein, possibly affecting the ability of this protein to complex or bind with its ligand.

interactions using a liquid $\beta$-galactosidase assay. In repeated experiments, we observed a significant decrease of $\approx 50 \%$ in the binding of L65P with CDK4, compared with the wild-type pl6 at both $30^{\circ}(\mathrm{p}=0.002)$ and $37^{\circ}(\mathrm{p}=0.009$; Student's $t$ test) (fig 3 ). These results are consistent with the predictions of the protein modelling, in that the effect of the L65P mutation on CDK4 binding is rather modest. In contrast to other pl6 missense mutations, ${ }^{50}$ the L65P mutant does not demonstrate any temperature dependence on binding of CDK4.

\section{$P 14^{A R F}$ ( $\beta$ transcript), CDKN2B, and CDK4 genes}

Among the 36 families tested for CDK4 mutations, one family had a CDK4 alteration in exon 7: a $G$ to A transition at $3170 \mathrm{bp}$, which changed the amino acid 240, arginine to glutamine. The proband with multiple melanomas, his unaffected mother ( 83 years old) and one of his unaffected sons ( 23 years old) showed this same mutation. However, the other cutaneous malignant melanoma case in this family did not have this mutation, so the importance of this alteration is unclear. No other disease related mutations were found in CDK4.

We tested 23 families for germline mutations in $C D K N 2 B$ or $p 14^{A R F}$ (exon $\beta$ ) but detected no mutations in the coding region of either gene. Cases from two families had the CDKN2B polymorphism rs2069426 in intron l (IVS1-27). Genotype frequencies of this single nucleotide polymorphism were measured using an MboI RFLP in 65 European Americans and 89 African-Americans. ${ }^{51}$ The heterozygote frequency was $20.0 \%$ and $10.1 \%$, and the homozygote frequency was $1.5 \%$ and $2.2 \%$ in the two populations, respectively.

\section{CDH 1 and BRCA2 genes}

In addition to the three families with pancreatic cancer, additional tumours have been reported in the families, but not histologically confirmed. In 19 families with one or more relatives with gastric cancer, and in three families with multiple breast cancer cases, in addition to the melanoma cases, we sequenced the $C D H 1$ and $B R C A 2$ genes, respectively. Mutations or altered expression of the CDHI gene (MIM *192090), on chromosome 16q22.1, have been associated with inherited diffuse gastric cancer. ${ }^{46}{ }^{52}$ BRCA2 gene (MIM ${ }^{*} 600185$ ), on chromosome 13q12.3, is a known susceptibility gene for breast cancer ${ }^{53}$ and melanoma. ${ }^{54}$ In our study, we failed to detect any mutations in the coding region of either the $C D H 1$ or $B R C A 2$ genes. The families screened for $C D H 1$ and $B R C A 2$ were also negative for mutations in the other melanoma candidate genes tested.

\section{Linkage analysis of chromosomes 1 and 9}

After the exclusion of non-informative families and those with disease related gene mutations, 47 and 46 families were used for linkage analysis of chromosome 1 and 9 , respectively.

We performed two point and multipoint linkage analyses under a dominant model with $50 \%$ penetrance, consistent with the inheritance pattern for CDKN2A in European families, ${ }^{15}$ and similar to the lp linkage studies. ${ }^{6-8}$ There was no evidence for linkage to either chromosome 1 or 9 (figs 4 and 5) in both parametric and non-parametric analyses. There was no significant evidence for genetic heterogeneity. For chromosome 1, the maximum two point lod score was $0.33 \quad(=0.25)$ at D1S207 (p22.3). For chromosome 9, the maximum two point lod score was 0.67 $(=0.15)$ at D9S161. The markers flanking CDKN2A (D9S157 and D9S171) had negative lod scores.

\section{DISCUSSION}

We studied a large number of Italian families, mostly from the Emilia Romagna and Marche regions, and found a low frequency of CDKN2A mutations, no mutations in other known candidate genes, and no evidence for linkage with previously suggested loci for possible melanoma susceptibility genes.

Melanoma aetiology is complex, involving both heterogeneous genetic and environmental components. ${ }^{55}$ The known susceptibility genes explain only approximately $25 \%$ of familial melanoma worldwide, and the frequency of CDKN2A mutations in familial melanoma varies according to the number of cases in the families, the presence of multiple melanomas in the same patient, ${ }^{5657}$ the history of pancreatic cancer cases in the family, ${ }^{58}$ and their geographical location. ${ }^{15}$ 59-62 Even the average lifetime risk conferred by CDKN2A mutations shows significant variation between regions, with the lowest penetrance in the south European countries. ${ }^{15}$ Moreover, subjects in families prone to melanoma often carry multiple common melanocytic nevi and atypical or dysplastic nevi, ${ }^{63}$ but development of melanoma through pathways that do not include nevi formation are likely, and they may be linked to different genes. ${ }^{64}$ Indeed, a few families in our study group, also including the kindred with the GlolW mutation and a case of pancreatic cancer, had no appreciable dysplastic nevi.

Previous studies conducted in Italian melanoma prone families have shown a relatively high proportion of CDKN2A mutations in the kindreds. In a study conducted in families coming mostly from the Liguria region-that is, in the northwestern part of Italy, where a founder mutation in exon 2 , G101W, has been identified, ${ }^{65}$ the frequency of mutations ranged from $7 \%$ in families with only two cases, to $67 \%$ in families with three cases, and $100 \%$ in families with four cases. ${ }^{18} 4765$ In central Italy, 4 out of 10 melanoma kindreds with at least two cases in first or second degree relatives had CDKN2A mutations $(40 \%)^{19}$ while in the Milan area, in northern Italy, $25 \%$ of families with two cases and $50 \%$ of families with three cases had $C D K N 2 A$ mutations. ${ }^{16}$ In our study, CDKN2A mutations were present in $7.3 \%$ of melanoma 


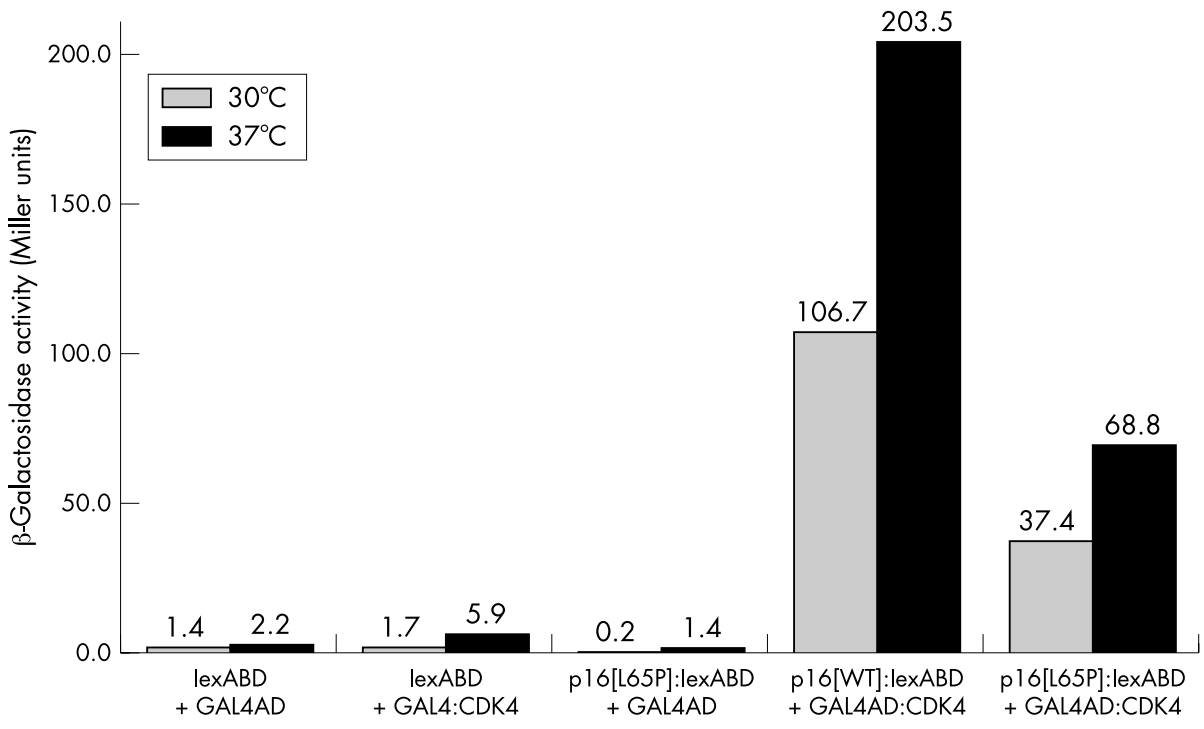

Expressed two hybrid fusion proteins

Figure 3 Abnormal p16 (L65P) binding to CDK4 in the yeast two hybrid system. Quantitative analysis of $\beta$-galactosidase activity was performed using a liquid $\beta$-galactosidase assay. The vectors pBTM1 16, pACTII, pACTII-GAL4 $A_{A D}$ :CDK4, pBTM1 16-p16L65P:lexABD, and pBTM1 16-p16WT:lexABD harbour the genes lexABD, GALAAD, GALAAD:CDK4, p16L65P:lexABD, and p16WT:lexABD, respectively. Different pairs of vectors were transformed into the yeast strain RAY43 and grown on synthetic complete media lacking leucine and tryptophan. The listed values represent the mean of either at least 28 separate assays performed at $30^{\circ} \mathrm{C}$ or 20 separate assays performed at $37^{\circ} \mathrm{C}$. Statistically significant differences $(\alpha=0.05)$ were observed between the wild-type variant and the L65P mutant at both $30^{\circ} \mathrm{C}(p=0.002)$ and at $37^{\circ} \mathrm{C}(p=0.009)$.

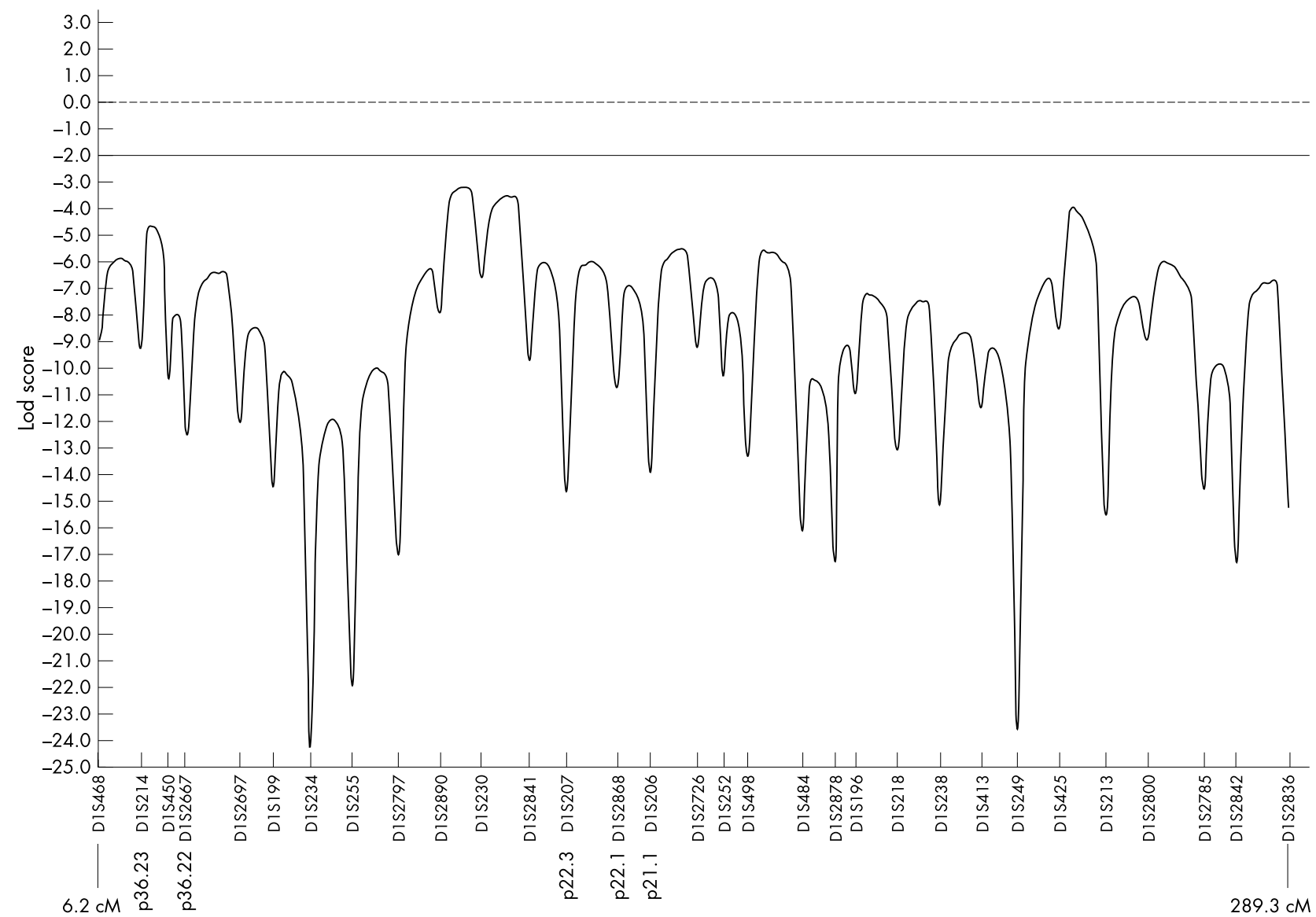

Figure 4 Parametric multipoint linkage analysis of chromosomes 1. The analysis was performed using GENEHUNTER (v. $2.0 \beta)$, assuming an autosomal dominant inheritance model with $50 \%$ penetrance. Forty seven families were tested with 31 dinucleotide microsatellite markers at approximately $10 \mathrm{cM}$. No evidence for linkage at any locus is shown. 


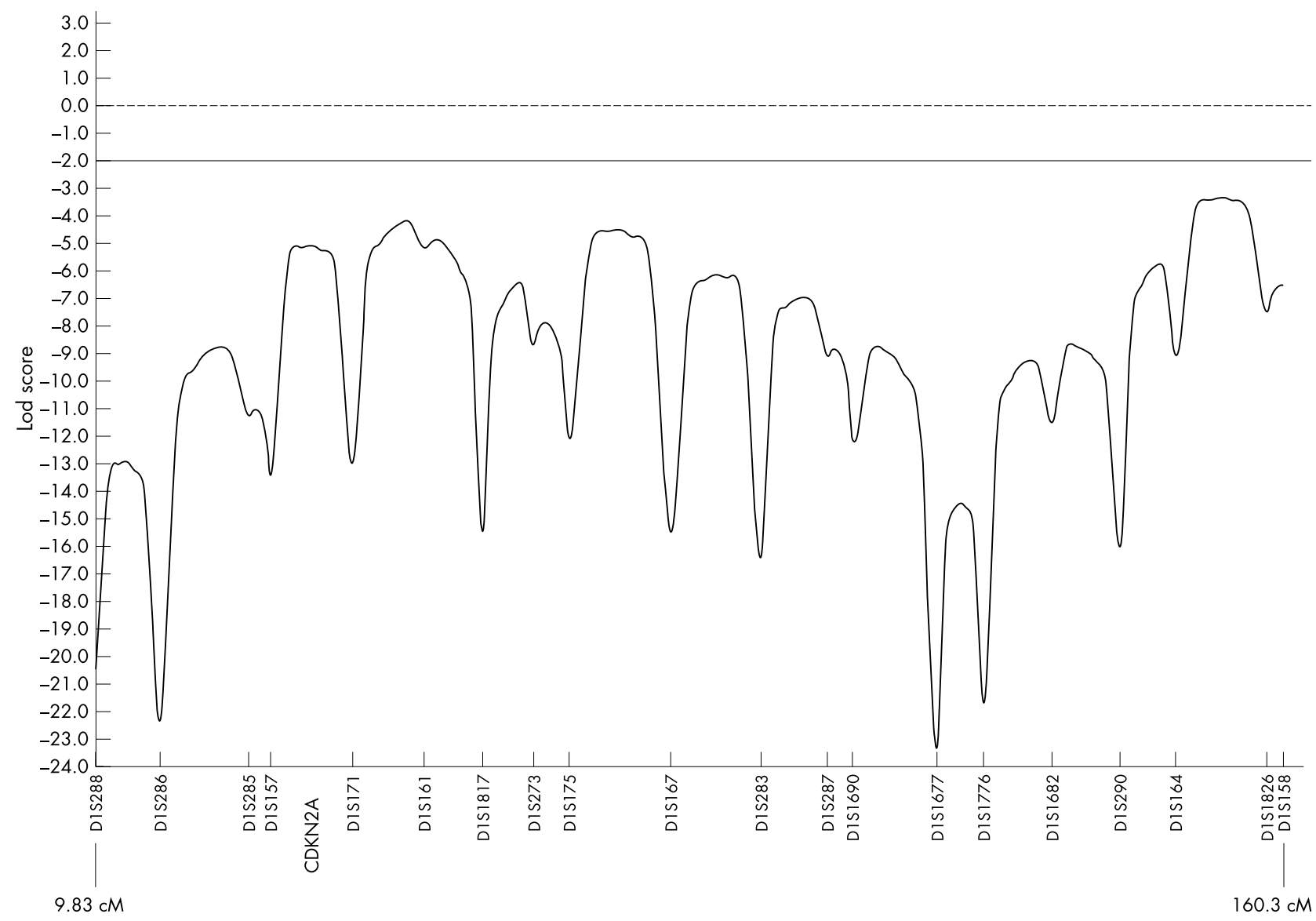

Figure 5 Parametric multipoint linkage analysis of chromosomes 9. The analysis was performed using GENEHUNTER (V. $2.0 \beta$ ), assuming an autosomal dominant inheritance model with $50 \%$ penetrance. Forty six families were tested with 20 dinucleotide microsatellite markers at approximately $10 \mathrm{cM}$. No evidence for linkage at any locus is shown.

kindreds overall, but only $7.7 \%(1 / 13)$ in families with $\geqslant 3$ affected individuals. If we restrict the assessment to only the families of the Emilia Romagna and Marche regions, $6.8 \%$ of families were positive for any mutation, and this rate is probably representative of the melanoma kindreds of the area, since at least $85 \%$ of their melanoma cases were diagnosed at the Bufalini Hospital during our study period.

A recent publication from the Melanoma Genetics Consortium has provided evidence for a novel susceptibility gene for melanoma within chromosome band $1 p 22 .{ }^{6}$ The study was restricted to melanoma pedigrees comprising at least three affected members, which were mutation negative for both CDKN2A and CDK4, had no evidence of haplotype sharing in the 9p21-22 region, and were from different areas of the world. We examined this region, as well as $1 p 36^{7}$ in our families using 31 microsatellite markers on chromosome 1 and found no evidence for linkage to either lp region (fig 4). In addition, our families showed no evidence for linkage to chromosome 9 (fig 5). Although we did not use many markers in the 9p21-22 region, there was no suggestion for linkage to chromosome $9 \mathrm{p}$. Further analysis of the remaining chromosomes may reveal other loci possibly linked to melanoma in this Mediterranean population.

It is possible that the clustering of cutaneous malignant melanoma cases in the Emilia Romagna population occurred by chance alone, as the majority of these families have only two relatives with cutaneous malignant melanoma, and a few melanoma cases also carried other tumours (table 1), possibly representing different syndromes, with low probability of CDKN2A mutations. ${ }^{66}$ In addition, the population of the area, known for its sea resorts, is likely to have intense exposure to the sun. Notably, two families whose members had a CDKN2A mutation and developed melanoma also spent some years in Africa. Previous studies have shown that sun exposure may increase melanoma risk beyond that accounted for by germline mutations alone, ${ }^{596267}$ and possibly modify the penetrance of $C D K N 2 A$ gene mutations. ${ }^{15}$ However, in Mediterranean countries, and in particular in Italy, incidence rates of melanoma are relatively low, with 4.6 cases/100 000 person years for men and 5.5 cases/100 000 person years for women ${ }^{68}$ and a cumulative risk of developing melanoma over a life time of $0.5 \%{ }^{2}$ Because of this low incidence, it is unlikely that familial aggregation is due to chance alone in this population. Moreover, all previous studies conducted in Italy on familial melanoma, which identified many individuals with CDKN2A mutations (in 33\% of all previously screened families), were based on similar numbers of cases per family. ${ }^{17} 197$ In addition, several of the Romagna kindreds included members with multiple primary melanomas (even in the families with melanomas only in second or higher degree relatives), or melanomas diagnosed at young ages, which often indicates an underlying genetic predisposition to the disease, ${ }^{50}$ and three families also had family members with pancreatic cancer, which has been associated with presence of CDKN2A mutations. ${ }^{18586970}$ In addition, we found a high frequency of reported breast cancer, as previously noted in families prone to melanoma, ${ }^{18}{ }^{69}$ and of gastric cancer, which is the fourth most common cancer in Europe, ${ }^{71}$ but we found no mutations in the $C D H 1$ and BRCA2 genes, making it unlikely that these 
kindreds represent clustering of different cancer types or syndromes.

Based on these considerations, it is curious that our mutation detection rate was so low. In this Italian subpopulation, there exist either non-coding susceptibility alleles of $C D K N 2 A$ that we cannot detect using current methods, or germline alterations of a genes other than $C D K N 2 A$ that play an important role in melanoma predisposition. Therefore, the Emilia Romagna population may prove to be a rich source for further genetic studies in melanoma in the future.

Among the four CDKN2A mutations identified in our study, one was not reported before: a leucine to proline missense mutation at position 65. Perturbations in the primary structure of pl6 can lead to profound loss of its inhibitory activity, ${ }^{72}$ but existing functional assays have frequently reached conflicting conclusions. ${ }^{73}$ We studied the possible effects of the mutation on both the predicted protein structure (fig 2) and its experimentally determined interaction with CDK4 (fig 3). The leucine at position 65 is not conserved across species, and molecular modelling suggests that its replacement by proline will produce surprisingly little effect on the tertiary structure of the protein. In keeping with this supposition, the yeast two hybrid interaction assay demonstrated only a modest reduction in the binding of the L65P mutant to CDK4, when compared with the wild-type p16. Nonetheless, the corresponding allele does cosegregate with disease in at least one family. The phenotypic effect of L65P mutation may exceed that predicted by the yeast assay. This observation is in keeping with that of other investigators. For instance, Becker et $\mathrm{al}^{74}$ have demonstrated that some pl6 mutants fail to induce growth arrest despite retaining normal binding to CDK4. They suggested that such pl6 mutations may confer a predisposition to melanoma through a mechanism not yet identified. We speculate that pl6 interacts with as yet unidentified proteins, and thus plays a role in tumour suppression that is distinct from its effect on the retinoblastoma pathway, mediated by CDK4.

In addition, another protein may be defective and modify the effect of the mutant L65P in this family. The melanocortin-1 receptor (MClR) gene (OMIM 155555) on chromosome $16 \mathrm{q} 24.3$ is a possible low-penetrance candidate gene which has been associated with fair complexion and melanoma in a few families, ${ }^{75}$ and may act as a modifier of the CDKN2A gene. ${ }^{76}{ }^{77}$ We screened the 11 members of the family carrying the p16 L65P mutation for the most common variants of the $M C 1 R$ gene, as part of an on-going study on the association between $M C 1 R$ variants and melanoma. Nine individuals $(81 \%)$ carried $M C 1 R$ variants, and precisely the missense V92M and silent T314T. All subjects with pl6 L65P, including the three living melanoma cases and the unaffected individual, carried these variants. Thus, MCIR does not appear to be informative in this family.

Many melanoma cases identified in our study, as well as in a parallel case-control study of sporadic melanoma conducted in the same area, ${ }^{22}$ were advanced in stage. This suggests that this population does not generally appreciate the risk for melanoma, and would benefit from public health campaigns against unprotected sun exposure, and from frequent screenings and better understanding of the etiology of the disease. As the incidence and mortality of melanoma continue to increase, particularly in Southern European countries such as Italy, identification of novel genes may have considerable clinical impact on familial melanoma.

\section{ACKNOWLEDGEMENTS}

We are indebted to the study families for their participation. We deeply thank Drs Margaret Tucker, Pier Alberto Bertazzi, and Giorgio Landi for their advice and support; Paola Minghetti and Tracy Franzos for the study management and biospecimen collection and processing; Kris Pike, Teri Plona, and David Sun for their technical assistance in the laboratory analyses; and Michael Beerman for his support in the database management.

\section{Authors' affiliations}

M T Landi, A M Goldstein, M Ter-Minassian, Genetic Epidemiology Branch, Division of Cancer Epidemiology and Genetics, National Cancer Institute, NIH, DHHS, Bethesda, MD

S Tsang, D Munroe, Laboratory of Molecular Technology, National Cancer Institute, SAIC, NIH, DHHS, Frederick, MD

W Modi, M Dean, N Metheny, Basic Research Program, National Cancer Institute, SAIC, NIH, DHHS, Frederick, MD

R Steighner, B Staats, Core Genotyping Facility, Advanced Technology Center, National Cancer Institute, NIH, DHHS, Gaithersburg, MD

R Agatep, D Hogg, Departments of Medicine and Medical Biophysics, The University of Toronto, and the University Health Network, Toronto, Ontario, Canada

D Calista, Dermatology Unit, Maurizio Bufalini Hospital, Cesena, Italy

Conflict of interest: none declared.

Correspondence to: M T Landi, MD, PhD, Genetic Epidemiology Branch, Division of Cancer Epidemiology and Genetics, National Cancer Institute, NIH, DHHS, 6120 Executive Blvd, EPS Room 7114, Bethesda, 20892-7236; landim@mail.nih.gov

Received 27 November 2003

Accepted for publication 22 December 2003

\section{REFERENCES}

1 De Vries E, Bray Fl, Coebergh JW, Parkin DM. Changing epidemiology of malignant cutaneous melanoma in Europe 1953-1997: rising trends in incidence and mortality but recent stabilizations in western Europe and decreases in Scandinavia. Int J Cancer 2003;107:1 19-26.

2 Balzi D, Carli P, Geddes M. Malignant melanoma in Europe: changes in mortality rates (1970-90) in European Community countries. Cancer Causes Control 1997; 8:85-92.

3 Greene MH, Fraumeni JF Jr. The hereditary variant of malignant melanoma In: Clark WH Jr, Mastrangelo $\sqcup$, Goldman LI, eds. Human malignant melanoma. New York: Grune and Stratton, 1979:139-66.

4 Aitken JF, Youl P, Green A, MacLennan R, Martin NG. Accuracy of casereported family history of melanoma in Queensland, Australia. Melanoma Res 1996;6:313-7

5 Calista D, Goldstein AM, Landi MT. Familial melanoma aggregation in northeastern Italy. J Invest Dermatol 2000;115:764-5.

6 Gillanders E, Hank Juo SH, Holland EA, Jones M, Nancarrow D, Freas-Lutz D, Sood R, Park N, Faruque M, Markey C, Kefford RF, Palmer J, Bergman W, Bishop DT, Tucker MA, Bressac-de Paillerets B, Hansson J, Stark M, Gruis N, Bishop JN, Goldstein AM, Bailey-Wilson JE, Mann GJ, Hayward N, Trent J. Localization of a novel melanoma susceptibility locus to 1p22. Am J Hum Genet 2003;73:301-13.

7 Bale SJ, Dracopoli NC, Tucker MA, Clark WH Jr, Fraser MC, Stanger BZ, Green P, Donis-Keller H, Housman DE, Greene MH. Mapping the gene for hereditary cutaneous malignant melanoma-dysplastic nevus to chromosome 1p. N Engl J Med 1989:320:1367-72.

8 Goldstein AM, Dracopoli NC, Ho EC, Fraser MC, Kearns KS, Bale SJ, McBride OW, Clark WH Jr, Tucker MA. Further evidence for a locus for cutaneous malignant melanoma-dysplastic nevus (CMM/DN) on chromosome $1 \mathrm{p}$, and evidence for genetic heterogeneity. Am J Hum Genet 1993:52:537-50

9 Kamb A, Shattuck-Eidens D, Eeles R, Liu Q, Gruis NA, Ding W, Hussey C, Tran T, Miki Y, Weaver-Feldhaus J. Analysis of the pl6 gene (CDKN2) as a candidate for the chromosome 9p melanoma susceptibility locus. Nat Genet 1994;8:23-6.

10 Nobori T, Miura K, Wu DJ, Lois A, Takabayashi K, Carson DA. Deletions of the cyclin-dependent kinase-4 inhibitor gene in multiple human cancers. Nature 1994;368:753-6.

11 Wolfel T, Hauer M, Schneider J, Serrano M, Wolfel C, Klehmann-Hieb E, De Plaen E, Hankeln T, Meyer zum Buschenfelde KH, Beach D. A pl6INK4ainsensitive CDK4 mutant targeted by cytolytic $T$ lymphocytes in a human melanoma. Science 1995;269:1281-4.

12 Brotherton DH, Dhanaraj V, Wick S, Brizuela L, Domaille PJ, VolyanikE, Xu X, Parisini E, Smith BO, Archer SJ, Serrano M, Brenner SL, Blundell TL, Laue E, eds. Crystal structure of the complex of the cyclin D-dependent kinase Cdk6 bound to the cell-cycle inhibitor p19INK4d. Nature 1998;395:244-50.

13 Randerson-Moor JA, Harland M, Williams S, Cuthbert-Heavens D, Sheridan E, Aveyard J, Sibley K, Whitaker L, Knowles M, Bishop JN, Bishop DT. A germline deletion of p14(ARF) but not CDKN2A in a melanomaneural system tumour syndrome family. Hum Mol Genet 2001;10:55-62.

14 Rizos H, Puig S, Badenas C, Malvehy J, Darmanian AP, Jimenez L, Mila M, Kefford RF. A melanoma-associated germline mutation in exon $1 \beta$ inactivates pl 4ARF. Oncogene 2001;20:5543-7.

15 Bishop DT, Demenais F, Goldstein AM, Bergman W, Bishop JN, Bressac-de Paillerets B, Chompret A, Ghiorzo P, Gruis N, Hansson J, Harland M, Hayward N, Holland EA, Mann GJ, Mantelli M, Nancarrow D, Platz A, Tucker MA. Geographical variation in the penetrance of CDKN2A mutations for melanoma. J Natl Cancer Inst 2002;94:894-903. 
16 Della TG, Pasini B, Frigerio S, Donghi R, Rovini D, Delia D, Peters G, Huot TJ, Bianchi-Scarra G, Lantieri F, Rodolfo M, Parmiani G, Pierotti MA. CDKN2A and CDK4 mutation analysis in Italian melanoma-prone families: functional characterization of a novel CDKN2A germ line mutation. $\mathrm{Br} J$ Cancer 2001;85:836-44.

17 Ciotti P, Strigini P, Bianchi-Scarra G. Familial melanoma and pancreatic cancer. Ligurian Skin Tumor Study Group. N Engl J Med 1996;334:469-70.

18 Ghiorzo P, Ciotti P, Mantelli M, Heouaine A, Queirolo P, Rainero ML, Ferrari C, Santi PL, De Marchi R, Farris A, Ajmar F, Bruzzi P, BianchiScarra G. Characterization of ligurian melanoma families and risk of occurrence of other neoplasia. Int J Cancer 1999;83:441-8.

19 Fargnoli MC, Chimenti S, Keller G, Soyer HP, Dal P, V, Hofler H, Peris K. CDKN2a/pl6INK4a mutations and lack of p19ARF involvement in familial melanoma kindreds. J Invest Dermatol 1998:111:1202-6.

20 Casula M, Ascierto PA, Cossu A, Sini MC, Tore S, Colombino M, Satta MP, Manca A, Rozzo C, Satriano SM, Castello G, Lissia A, Tanda F, Palmieri G. Mutation analysis of candidate genes in melanoma-prone families: evidence of different pathogenetic mechanisms at chromosome 9P21. Melanoma Res 2003;13:571-9.

21 Parkin DM, Whelan SL, Ferlay J, Raymond L, Young J, eds. Cancer Incidence in Five Continents. Vol 7. Lyon: International Agency for Research on Cancer, 1997.

22 Landi MT, Baccarelli A, Calista D, Pesatori A, Fears T, Tucker MA, Landi G. Combined risk factors for melanoma in a Mediterranean population. Br J Cancer 2001;85: 1304-10.

23 Landi MT, Calista D, Landi G, Bernucci I, Bertazzi PA, Clark WH Jr, Goldstein AM, Tucker MA. Clinical characteristics of 20 Italian melanomaprone families. Arch Dermatol 1999;135:1554-5.

24 Castellano M, Pollock PM, Walters MK, Sparrow LE, Down LM, Gabrielli BG Parsons PG, Hayward NK. CDKN2A/pl6 is inactivated in most melanoma cell lines. Cancer Res 1997:57:4868-75.

25 Pollock PM, Stark MS, Palmer JM, Walters MK, Aitken JF, Martin NG, Hayward NK. Mutation analysis of the CDKN2A promoter in Australian melanoma families. Genes Chromosomes Cancer 2001;32:89-94.

26 Werle E, Schneider C, Renner M, Volker M, Fiehn W. Convenient single-step one tube purification of PCR products for direct sequencing. Nucleic Acids Res 1994;22:4354-5.

27 Liu L, Lassam NJ, Slingerland JM, Bailey D, Cole D, Jenkins R, Hogg D. Germline p16INK4A mutation and protein dysfunction in a family with inherited melanoma. Oncogene 1995;11:405-12.

28 Mao L, Merlo A, Bedi G, Shapiro Gl, Edwards CD, Rollins BJ, Sidransky D. A novel pl6INK4A transcript. Cancer Res 1995;55:2995-7.

29 Zuo L, Weger J, Yang Q, Goldstein AM, Tucker MA, Walker GJ, Hayward N, Dracopoli NC. Germline mutations in the p16INK4a binding domain of CDK4 in familial melanoma. Nat Genet 1996;12:97-9.

30 Shennan MG, Badin AC, Walsh S, Summers A, From L, McKenzie M, Goldstein AM, Tucker MA, Hogg D, Lassam N. Lack of germline CDK6 mutations in familial melanoma. Oncogene 2000;19:1849-52.

31 Cottingham RW Jr, Idury RM, Schaffer AA. Faster sequential genetic linkage computations. Am J Hum Genet 1993;53:252-63.

32 Schaffer AA, Gupta SK, Shriram K, Cottingham RW Jr. Avoiding recomputation in linkage analysis. Hum Hered 1994:44:225-37.

33 Kruglyak L, Daly MJ, Reeve-Daly MP, Lander ES. Parametric and nonparametric linkage analysis: a unified multipoint approach. Am J Hum Genet 1996;58:1347-63.

34 Verdecchia A, Micheli A, Colonna M, Moreno V, Izarzugaza MI, Paci E. A comparative analysis of cancer prevalence in cancer registry areas of France, Italy and Spain. Ann Oncol 2002;13:1 128-39.

35 O'Connell JR, Weeks DE. PedCheck: a program for identification of genotype incompatibilities in linkage analysis. Am J Hum Genet 1998:63:259-66.

36 Broman KW, Murray JC, Sheffield VC, White RL, Weber JL. Comprehensive human genetic maps: individual and sex-specific variation in recombination. Am J Hum Genet 1998;63:861-9.

37 OHt J. Linkage analysis and family classification under heterogeneity. Ann Hum Genet 1983:47:311-20.

$38 \mathrm{OHt}$ J. Analysis of human genetic linkage. Rev ed. Baltimore, MD: Johns Hopkins University Press, 1996.

39 Guerois R, Nielsen JE, Serrano L. Predicting changes in the stability of proteins and protein complexes: a study of more than 1000 mutations. J Mol Biol 2002;320:369-87.

40 Gilis D, Rooman M. PoPMuSiC, an algorithm for predicting protein mutant stability changes: application to prion proteins. Protein Eng 2000;13:849-56

41 Sunyaev S, Lathe W III, Bork P. Integration of genome data and protein structures: prediction of protein folds, protein interactions and "molecular phenotypes" of single nucleotide polymorphisms. Curr Opin Struct Biol 2001;11:125-30

42 Guthrie C, Fink GR, eds. Guide to yeast genetics and molecular biology. Methods Enzymol 1991;194:1-863.

43 Bartel PL, Fields S. Analyzing protein-protein interactions using two-hybrid system. Methods Enzymol 1995;254:241-63.

44 Gietz RD, Woods RA. Transformation of yeast by lithium acetate/singlestranded carrier DNA/polyethylene glycol method. Methods Enzymol 2002;350:87-96.

45 Miller JH. Assay of $\beta$-galactosidase. In: Experiments in molecular genetics. Cold Spring Harbor: Cold Spring Harbor Laboratory Press, 1972:352-5.

46 Guilford P, Hopkins J, Harraway J, Mcleod M, Mcleod N, Harawira P, Taite $\mathrm{H}$, Scoular R, Miller A, Reeve AE. E-cadherin germline mutations in familial gastric cancer. Nature 1998;392:402-5.
47 Mantelli M, Barile M, Ciotti P, Ghiorzo P, Lantieri F, Pastorino L, Catricala C, Torre GD, Folco U, Grammatico P, Padovani L, Pasini B, Rovini D, Queirolo P, Rainero ML, Santi PL, Sertoli RM, Goldstein AM, Bianchi-Scarra G. High prevalence of the G101W germline mutation in the CDKN2A (P16(ink4a)) gene in 62 Italian malignant melanoma families. Am J Med Genet 2002;107:214-21.

48 Harland M, Holland EA, Ghiorzo P, Mantelli M, Bianchi-Scarra G, Goldstein AM, Tucker MA, Ponder BA, Mann GJ, Bishop DT, Newton BJ. Mutation screening of the CDKN2A promoter in melanoma families. Genes Chromosomes Cancer 2000;28:45-57.

49 Kumar R, Smeds J, Berggren P, Straume O, Rozell BL, Akslen LA, Hemminki K. A single nucleotide polymorphism in the $3^{\prime}$ 'untranslated region of the CDKN2A gene is common in sporadic primary melanomas but mutations in the CDKN2B, CDKN2C, CDK4 and p53 genes are rare. Int J Cancer 2001:95:388-93.

50 Monzon J, Liu L, Brill H, Goldstein AM, Tucker MA, From L, Mclaughlin J, Hogg D, Lassam NJ. CDKN2A mutations in multiple primary melanomas. N Engl J Med 1998;338:879-87.

51 Modi WS, Goedert JJ, Strathdee S, Buchbinder S, Detels R, Donfield S, O'Brien SJ, Winkler C. MCP-1-MCP-3-Eotaxin gene cluster influences HIV-1 transmission. AIDS 2003;17:2357-65.

52 Suriano G, Oliveira C, Ferreira P, Machado JC, Bordin MC, de Wever O, Bruyneel EA, Moguilevsky N, Grehan N, Porter TR, Richards FM, Hruban RH, Roviello F, Huntsman D, Mareel M, Carneiro F, Caldas C, Seruca R. Identification of $\mathrm{CDH} 1$ germline missense mutations associated with functional inactivation of the $\mathrm{E}$-cadherin protein in young gastric cancer probands. Hum Mol Genet 2003;12:575-82.

53 Wooster R, Bignell G, Lancaster J, Swift S, Seal S, Mangion J, Collins N, Gregory S, Gumbs C, Micklem G. Identification of the breast cancer susceptibility gene BRCA2. Nature 1995;378:789-92.

54 The Breast Cancer Linkage Consortium. Cancer risks in BRCA2 mutation carriers. J Natl Cancer Inst 1999:91:1310-6.

55 Kefford RF, Newton Bishop JA, Bergman W, Tucker MA. Counseling and DNA testing for individuals perceived to be genetically predisposed to melanoma: a consensus statement of the Melanoma Genetics Consortium. $J$ Clin Oncol 1999;17:3245-51.

56 Holland EA, Schmid H, Kefford RF, Mann GJ. CDKN2A (P16(INK4a)) and CDK4 mutation analysis in 131 Australian melanoma probands: effect of family history and multiple primary melanomas. Genes Chromosomes Cancer 1999;25:339-48.

57 Soufir N, Avril MF, Chompret A, Demenais F, Bombled J, Spatz A, StoppaLyonnet D, Benard J, Bressac-de Paillerets B. Prevalence of pl6 and CDK4 germline mutations in 48 melanoma-prone families in France. The French Familial Melanoma Study Group. Hum Mol Genet 1998;7:209-16.

58 Goldstein AM, Fraser MC, Struewing JP, Hussussian CJ, Ranade K, Zametkin DP, Fontaine LS, Organic SM, Dracopoli NC, Clark WH Jr. Increased risk of pancreatic cancer in melanoma-prone kindreds with pl6INK4 mutations. N Engl J Med 1995;333:970-4.

59 Cannon-Albright LA, Meyer L, Goldgar DE, Lewis CM, McWhorter WP, Jost $M$, Harrison D, Anderson DE, Zone JJ, Skolnick MH. Penetrance and expressivity of the chromosome 9p melanoma susceptibility locus (MLM). Cancer Res 1994;54:6041-4.

60 Hussussian CJ, Struewing JP, Goldstein AM, Higgins PA, Ally DS, Sheahan MD, Clark WH Jr, Tucker MA, Dracopoli NC. Germline p16 mutations in familial melanoma. Nat Genet 1994;8:15-21.

61 Goldstein AM, Tucker MA. Screening for CDKN2A mutations in hereditary melanoma. J Natl Cancer Inst 1997;89:676-8

62 Goldstein AM, Falk RT, Fraser MC, Dracopoli NC, Sikorski RS, Clark WH Jr, Tucker MA. Sun-related risk factors in melanoma-prone families with CDKN2A mutations. J Natl Cancer Inst 1998:90:709-11.

63 Greene MH. The genetics of hereditary melanoma and nevi. 1998 update. Cancer 1999;86:2464-77.

64 Goldstein AM, Goldin LR, Dracopoli NC, Clark WH Jr, Tucker MA. Two-locus linkage analysis of cutaneous malignant melanoma/dysplastic nevi. Am J Hum Genet 1996:58:1050-6.

65 Ciotti P, Struewing JP, Mantelli M, Chompret A, Avril MF, Santi PL, Tucker MA, Bianchi-Scarra G, Bressac-de Paillerets B, Goldstein AM. A single genetic origin for the G101W CDKN2A mutation in 20 melanoma-prone families. Am J Hum Genet 2000;67:31 1-9.

66 Alao JP, Mohammed MQ, Retsas S. The CDKN2A tumour suppressor gene: no mutations detected in patients with melanoma and additional unrelated cancers. Melanoma Res 2002;12:559-63.

67 Battistutta D, Palmer J, Walters M, Walker G, Nancarrow D, Hayward N. Incidence of familial melanoma and MLM2 gene. Lancet 1994:344:1607-8.

68 Ferlay J, Bray S, Sankila R, Parkin DM. EUCAN: cancer incidence, mortality and prevalence in the European Union 1996, version 3.1. IARC CancerBase No 4. Lyon: IARCPress, 1999. Limited version available from: www-dep.iarc.fr/eucan/eucan.htm. (accessed 2003).

69 Borg A, Sandberg T, Nilsson K, Johannsson O, Klinker M, Masback A, Westerdahl J, Olsson $\mathrm{H}$, Ingvar C. High frequency of multiple melanomas and breast and pancreas carcinomas in CDKN2A mutation-positive melanoma families. J Natl Cancer Inst 2000;92:1260-6.

70 Vasen HF, Gruis NA, Frants RR, Der Velden PA, Hille ET, Bergman W. Risk of developing pancreatic cancer in families with familial atypical multiple mole melanoma associated with a specific 19 deletion of p16 (pl6-Leiden). Int J Cancer 2000;87:809-11

71 Bray F, Sankila R, Ferlay J, Parkin DM. Estimates of cancer incidence and mortality in Europe in 1995. Eur J Cancer 2002;38:99-166.

72 Lilischkis R, Sarcevic B, Kennedy C, Warlters A, Sutherland RL. Cancerassociated mis-sense and deletion mutations impair p16INK4 CDK inhibitory activity. Int J Cancer 1996;66:249-54. 
73 Ruas M, Brookes S, McDonald NQ, Peters G. Functional evaluation of tumourspecific variants of $\mathrm{p} 161 \mathrm{NK} 4 \mathrm{a} / \mathrm{CDKN} 2 \mathrm{~A}$ : correlation with protein structure information. Oncogene 1999;18:5423-34.

74 Becker TM, Rizos H, Kefford RF, Mann GJ. Functional impairment of melanoma-associated pl6(INK4a) mutants in melanoma cells despite retention of cyclin-dependent kinase 4 binding. Clin Cancer Res retention of cyclin-d

75 Palmer JS, Duffy DL, Box NF, Aitken JF, O'Gorman LE, Green AC, Hayward NK, Martin NG, Sturm RA. Melanocortin-1 receptor polymorphisms and risk of melanoma: is the association explained solely by pigmentation phenotype? Am J Hum Genet 2000;66:176-86.

76 Van der Velden PA, Sandkuij LA, Bergman W, Pavel S, van Mourik L, Frants RR, Gruis NA. Melanocortin-1 receptor variant R151C modifies melanoma risk in Dutch families with melanoma. Am J Hum Genet 2001:69:774-9.

77 Box NF, Duffy DL, Chen W, Stark M, Martin NG, Sturm RA, Hayward NK $M C 1 R$ genotype modifies risk of melanoma in families segregating CDKN2A mutations. Am J Hum Genet 2001;69:765-73. 